\title{
Meta
}

Journal des traducteurs

Translators' Journal

\section{MA, H. J. (2003): A Study on Nida's Translation Theory, Beijing, Foreign Language Teaching and Research Press, 250 p.}

\section{$\mathrm{Xu}$ Jianzhong}

Volume 49, numéro 4, décembre 2004

URI : https://id.erudit.org/iderudit/009796ar

DOI : https://doi.org/10.7202/009796ar

Aller au sommaire du numéro

Éditeur(s)

Les Presses de l'Université de Montréal

ISSN

0026-0452 (imprimé)

1492-1421 (numérique)

Découvrir la revue

Citer ce compte rendu

Jianzhong, X. (2004). Compte rendu de [MA, H. J. (2003): A Study on Nida's

Translation Theory, Beijing, Foreign Language Teaching and Research Press,

250 p.] Meta, 49(4), 941-943. https://doi.org/10.7202/009796ar

Ce document est protégé par la loi sur le droit d'auteur. L'utilisation des services d'Érudit (y compris la reproduction) est assujettie à sa politique d'utilisation que vous pouvez consulter en ligne.

https://apropos.erudit.org/fr/usagers/politique-dutilisation/
Cet article est diffusé et préservé par Érudit.

Érudit est un consortium interuniversitaire sans but lucratif composé de l’Université de Montréal, l'Université Laval et l'Université du Québec à Montréal. Il a pour mission la promotion et la valorisation de la recherche. https://www.erudit.org/fr/ 
Ladmiral, J.-R. (1993): "Sourciers et ciblistes» dans Holz-Mänttäri, J. und C. Nord: Traducere Navem. Festschrift für Katharina Reiß, Tampere, Studia Translatologica, ser. A vol. 3. Lederer, M. (1994): La traduction aujourd'hui, Paris, Hachette.

Rickheit, G. und H. Strohner (1993): Grundlagen der kognitiven Sprachverarbeitung, Modelle, Methoden, Ergebnisse, Tübingen, Francke.

Stefanink, B. (1997) : «Esprit de finesse - Esprit de géométrie: Das Verhältnis von Intuition und übersetzerrelevanter Textanalyse" beim Übersetzen», dans R. Keller (Hrsg.) (1997): Linguistik und Literaturübersetzen, Tübingen, Narr, p. 161-183.

Wilss, W. (1988): Kognition und Übersetzen. Zu theorie und Praxis der menschlichen und maschinellen Übersetzung, Tübingen, Niemeyer.

\section{MA, H. J. (2003): A Study on Nida's Translation Theory, Beijing, Foreign Language Teaching and Research Press, $250 \mathrm{p}$.}

Eugene A. Nida (1914-) is a distinguished American translation theorist as well as linguist. His translation theory has exerted a tremendous influence on translation studies in western countries. His works on translation set off the study of modern translation as an academic field (Snell-Hornby 1988:1; Heylen 19993:4; Baker 1998:277), and he is regarded as the most influential one among all contemporary translation theorists (New Mark 1993:133).

Nida's influence upon Chinese translation studies is greater still. Before his theory was introduced into China in the 1980s, scholars mainly focused attention on traditional Chinese translation theories, especially Yan Fu's (1854-1921) three-character principle of translation, i.e. faithfulness, smoothness and elegance. Since Nida's theory was grounded solidly on contemporary developments of linguistics, communication theory, information theory, semiotics and anthropology, Chinese translation scholars took great interest in his theory. In fact, Nida's and his theory have been a hot topic in China for almost two decades. In the beginning, Nida's theory was extensively introduced and much discussed among translation scholars, and was given a high profile for its new perspectives on translation. As time went by, his theory was questioned and challenged. In recent years, his theory was strongly criticized, and even considered as outdated and having outlived its usefulness.

It is evident that Nida's translation theory has undergone dramatic ups and downs since it was introduced into China. This phenomenon is very interesting and has provoked a series of reflections on the part of the Chinese translation scholars. Why is there such a big change in Chinese translation scholars' attitudes towards Nida's theory? Are the criticisms against his theory justified? What are the demerits for which his theory is being severely criticized? Is his theory really useless or outdated for Chinese translation studies, as some scholars have so argued?

All these questions about Nida's theory are of great significance in the sense that, to some degree, they determine how Nida's theory will be received in the future Chinese translation studies. Something cautions us against taking leave of his theory without further consideration.

A Study on Nida's Translation Theory is the first attempt to make a systematic study on Nida's translation theory in the Chinese translation community. It reviews the reception of Nida's theory both in China and in the western countries from a historical perspective, explores its important concepts, such as his "science of translation," "dynamic equivalence"/ "functional equivalence," and the decoder's channel capacity. It also tries to clarify misunderstandings and misconceptions concerning his theory, including his theory of "reader's response," his advocacy of naturalizing translation, and the relationship between his "science of translation" and Chomsky's transformational generative grammar. Examples from Today's English Version and Today's Chinese Version of the Bible convincingly prove that, 
contrary to the popular assumption in the field of Chinese translation study, Nida's theory is, to a greater or lesser extent, applicable to translation practice between Chinese and other languages.

Despite the fact that the distinguished Chinese translation theorist Jin Di's (1921-) theory of "equivalent effect" is essentially similar to Nida's theory, there are some differences between them. In this monograph, a comparative study between the two theories is made with a view to disclosing their similarities and differences. Examples from Jin's Chinese version of James Joyce's Ulysses are examined against the principle of "equivalent effect," demonstrating that Nida's theory is applicable to literary translation between English and Chinese in three important aspects: 1) the application of "dynamic equivalence," 2) the significance of the concept of the decoder's channel capacity, and 3) the important role receptors play in evaluating literary translation. Thus this book tries to prove that the argument is untenable that his theory is irrelevant to English-Chinese literary translation.

While validating the strength of Nida's theory, the book tries to demonstrate its limitations in transferring aesthetic values in literary translation. This is probably because literary translation is not Nida's immediate concern and, therefore, he fails to address the issue of transference of aesthetic values. In this research, attempts have been made to add to his theory with further dimensions, that is, representing aesthetic values of literary works by means of "formal aesthetic markers" and "non-formal aesthetic markers," hoping to make it more suitable for literary translation between Chinese and English. The effect to amend Nida's theory along these lines is the first step toward this end.

From this book we obtain the following reflections:

When we examine a translation theory, we should concentrate on its true nature rather than its superficial meaning, and approach it in a comprehensive, dialectical and relative manner rather than in a partial, isolated and absolute way. Before judging a translation theory, we should make a thorough study of it, and then make the judgment in connection with practice, thus avoiding partial understanding and wrong conclusions.

Nida's theory has grown out of his experience of providing practical guidance for Bible translators. Admittedly, his theory is source-text oriented and prescriptive in a sense, but this should not be taken as the grounds for dismissing it as inapplicable and outdated. Pure translation theory is important, and there is no doubt about it, but applied theory has a significant role to play in improving translation quality. Supposing we take a descriptive approach to examine existing translations, and find a large number of them not up to the mark, the next thing we do is to improve them and that is where we need valid translation principles for help. What we mean is that applied theory is an important part in translation studies. Applied theory must not be rejected while pure theory is being emphasized. To be fair, we should not expect Nida's theory to cover all translation problems, especially those problems that the cultural studies approach of pure translation theory is concerned about. After all, translation is a complex phenomenon. Whatever approach, the translation is but one way of looking at the same thing from a specific angle. When evaluating a translation theory, we should see it as it is, we should not reject it with its strength because it has certain limitations.

Translation study as a discipline is to be viewed in various perspectives and developed by all theorists with what they have to offer. With the rapid development of translation studies, multi-approaches to translation are the inevitable trend. Nida's theory has attracted and will continue to attract attention with its great theoretical and practical values.

In sum, the book under review is very useful and will provide some fresh insights into Nida's theory, contribute to its application to translation practice, and promote the development of translation studies.

Xu JIANZHONG 


\section{REFERENCES}

BAKer, M. (1998): Routledge Encyclopedia of Translation Studies, London, Routledge.

Heylen, R. (1993): Translation Poetics and Stage: Six French Hamlets, London, Routledge.

Jin, D. (1998): In Search of the Principle of Equivalent Effect, Beijing, China Translation and Publishing Corporation.

Jin, D. (1994-1996): trans. Ulysses (You Li Xi Si) by James Joyce, Beijing, People's Literature Press. JIN, D. (2003): Literary Translation: Quest for Artistic Integrity, Manchester, St. Jerome.

Joyce, J. (1996): Ulysses, Nanjing, Yilin Press.

Newmark, P. (1993): Paragraphs on Translation, Clevedon, Multilingual Matters.

Snell-Hornby, M. (1988): Translation Studies: An Integrated Approach, Amsterdam, John Benjamins.

\section{O'Connell, E.M.T. (2003): Minority Language Dubbing for Children: Screen Transla- tion from German to Irish, Bern, Peter Lang, $211 \mathrm{p}$.}

This is a description of the considerations bearing on the dubbing of two series of German children's programs into Irish. It is also a critique of the translations underlying the dubbing in question. The original German (animated) television cartoon series both bore the title Janoschs Traumstunde, based on the work of Horst Eckert, a well known and widely translated author, whose pen name, at least for his numerous children's stories, is Janosch. The corpus for the study under review was composed of six of the original German programs and the Irish versions of each of them.

The first chapter, "Irish as a Minority Language" (pp. 33-63), recounts the external history of the Irish language in modern times and describes its present status. The author seems to take the position that Irish, though it is learned mainly in school, is a "Low" language in a diglossic relationship which is threatening to degenerate into language shift in favour of English (p. 43). We will be obliged to return to this status question.

Chapters Two and Three ("Dubbing," pp. 65-76, and "Synchrony," pp. 77-99) deal with technical aspects of "revoicing," the general term adopted by the author (p. 65) for four techniques: voice-over, narration, free commentary and lip-sync dubbing. This last is the technique used in the present corpus, a fact which leads the author to explain the types of synchrony required between the (moving) picture originally recorded and the audio script of the translation, which must "match" the movements of the characters, both articulatory and gestual, as well as other visual features of the film. She also evaluates the importance of these different types of synchrony in dubbing generally. Since the articulation of animated cartoon characters is not observable in as much detail as that of human television or film actors, however, the author does not criticize the dubbing of her corpus from this standpoint.

In fact, she does not criticize the dubbing as such, regarding it as "highly professional" (p. 76). Dubbing enters into her critique only insofar as she suspects that considerations of synchrony may have influenced certain parts of the Irish translation which was the input to the dubbing. It is the nature of this translation that is the real focus here. Thus Chapter Four deals with "Translating for Children" (pp. 101-121) and Chapter Five (pp. 123-186) presents the target of her critique: "Lexical Simplification."

The main criticism of the translations underlying the dubbing of this series of children's programs is the loss of information from the original German script, especially through choices within the target language lexicon (p. 28 and Chapter Five). In the author's view, speakers of Irish, and above all native speakers (especially the children, of course), should have been offered a richer and more challenging translation than that underlying the dubbed audio of these programs. More particularly, she says that the Irish version lost information from the original German script by the translating not only of specific terms by 